Urban Social Movements 


\section{Urban Social Movements}

The City After Castells

STUART LOWE

Macmillan Education 
ISBN 978-0-333-37520-4 ISBN 978-1-349-18175-9 (eBook)

DOI 10.1007/978-1-349-18175-9

(C) Stuart Lowe, 1986

Softcover reprint of the hardcover 1st edition 1986

All rights reserved. For information, write:

Scholarly \& Reference Division,

St. Martin's Press, Inc., 175 Fifth Avenue, New York, NY 10010

First published in the United States of America in 1986

ISBN 978-0-312-83470-8

Library of Congress Cataloging-in-Publication Data

Lowe, Stuart, 1950-

Urban social movements.

Bibliography: $p$.

Includes index.

1. Cities and towns-History-Cross-cultural

studies. 2. Social movements-History-Cross-cultural

studies. 3. Castells, Manuel-Criticism and interpre-

tation. I. Title.

HT119.L69 $1986 \quad 307.7$ '6 $\quad 85-22301$

ISBN 978-0-312-83470-8 
For Sue 


\section{Contents}

Acknowledgements $\quad$ ix

$\begin{array}{ll}\text { Introduction } & 1\end{array}$

1 Castells on Urban Social Movements 8

The urban domain $\quad 9$

Urban social movements - phase one $\quad 17$

Urban social movements - phase two 19

2 The City and the Grassroots $\quad 29$

Urban social change $\quad 30$

Urban social movements -- phase three 33

Conclusion $\quad 48$

3 The Mobilisation Process 55

The local political system $\quad 55$

Social bases and the mobilisation process $\quad 60$

Ideologies of the urban system $\quad 76$

$\begin{array}{ll}\text { Conclusion } & 80\end{array}$

4 Public Sector Housing Movements 82

Council estates as social bases $\quad 82$

Tenants' associations in Britain $\quad 84$

The tenants' movement in Sheffield (1967-84) 94

Political strategies of the tenants' movement 110 
viii Contents

5 Ideologies in Local Politics - The Ratepayers' and Squatters' Movements

The ratepayers' movement

Barnsley Ratepayers' Association

The squatters' movement

Conclusion

6 Comparative Urban Social Movements

Models of change - the growth or decline of urban social movements?

Italy, France and Spain

An environmental movement in an East European socialist state

Social movements in the United States of America

The shanty-towns of South America

Models for comparing urban social movements

Conclusion

7 The Theory and Practice of Urban Social

Movements

Castells's new urban social movements

Analysing urban social movements

Urban social movements in Britain in the 1980 s 


\section{Acknowledgements}

The genesis of this book can be precisely located; it began when Dilys Hill, during the viva for my doctoral thesis, urged me to read in more detail the new urban politics literature. This I subsequently did, and discovered more of its treasures and pitfalls. I am, of course, very grateful to my supervisors at that time, Bill Hampton and Patrick Seyd, for their help in steering me through the hazardous exercise of thesis writing. It was due to them that I set about the long process of seeking a publisher. The end product, however, bears little resemblance to the thesis, although it was a vital stage in the intellectual preparation.

The first version of the text was written while I was working as a tutor organiser for the Workers' Educational Association in South Yorkshire; and it bore, at that stage, the hallmarks of that relatively isolated occupation. The current version has been formulated since I moved to the University of York, and became able to contact a wider academic community. Peter Saunders, Michael Harloe and Bill Hampton generously gave time to comment on drafts of the early chapters. Bill Hampton and Kathleen Jones kindly read at short notice the nearly complete text and made some very useful suggestions. Many thanks are due to James Simmie for suggesting how the first version could be made into a publishable commodity and trusting me to do the job. The creative environment generated by Kathleen Jones in the Department of Social Policy and Social Work has spurred me on. Our indispensable secretary, Alison Holdsworth, proof-read the manuscript and typed some of the draft version. I am very grateful to Janice Vanham for typing most of the draft and all of the final text. 
x Acknowledgements

But the greatest debt of all is owed to my family for making it possible for me to spend the hundreds of hours necessary to produce a book of this type.

January 1985

Stuart Lowe 